\title{
Hubungan Self Awareness dengan Kedisiplinan Peserta Didik Kelas VIII di SMP Wiyatama Bandar Lampung ( Penelitian Korelasional Bidang BK Pribadi )
}

\author{
Laila Maharani, Meri Mustika
}

Dosen Fakultas Tarbiyah dan Keguruan, IAIN Raden Intan Bandar Lampung

Diterima: 5 Januari 2016. Disetujui: 17 Februari 2016. Dipublikasikan: Mei 2016

\begin{abstract}
Abstrak: Kedisiplinan merupakan sesuatu yang penting bagi peserta didik,namun demikian masih banyak peserta didik SMP Wiyatama Bandar Lampung yang belum disiplin, hal ini tampak pada perilaku peserta didik di sekolah, yaitu masih adanya peserta didik yang melanggar kedisiplinan dan tata tertib yang berlaku di sekolahdiantaranya terlambat datang ke sekolah 14 peserta didik, tidak disiplin dalam berseragam 7 peserta didik, malas dalam mengerjakan tugas-tugas 4 peserta didik, kurang bisa belajar sendiri 6peserta didik, malas dalam mengerjakan tugas-tugas 5 peserta didik, sering menyontek hasil pekerjaan temannya 17 peserta didik, mengerjakan tugas PR saat mengikuti mata pelajaran 7 peserta didik,karena sikap disiplin peserta didik juga berhubungan dengan kesadaran diri dalam diri peserta didik.Self awareness dengan tujuan untuk meningkatkan kedisiplinan peserta didik sudah dilaksanakan oleh guru pembimbing SMP Wiyatama Bandar Lampung, tetapi belumefektif. Tujuan dari penelitian ini adalahuntuk mengetahui hubungan self - awareness dengan kedisiplinan peserta didik di SMP Wiyatama Bandar Lampung. Penelitian ini menggunakan penelitian kuantitatif korelasional menggunakan pendekatan cross sectional. Populasi penelitian adalah kelas VIII SMP Wiyatama Bandar Lampung sejumlah 120 peserta didik kemudian teknik sampling yang digunakan yaitu purposive sampling, sampel yang di ambil sebanyak 60 peserta didik kelas VIII, teknik pengumpulan data yang digunakan yaitu angket, observasi, dan wawancara. Hasil penelitian bahwa sikap disiplin masih dimiliki peserta didik SMP Wiyatama Bandar Lampung. Hal ini dapat dibuktikan oleh hasil penelitian menujukan bahwa peserta didik yang tergolong memiliki kesadaran diri (self awareness) tertutup memiliki persentase sebesar $41,7 \%$ dan yang terbuka sebesar $58,3 \%$. Lalu peserta didik yang disiplin memiliki persentase $78,3 \%$ dan yang tidak disiplin $21,7 \%$ yang membuktikan kedisipinan pada peserta didik kelas VIII di SMP Wiyatama Bandar Lampung. (p-value $=0,001$ yang berarti $\mathrm{p}<\alpha$ ). Peneliti menyarankan agar pihak sekolah dapat membantu peserta didik dalam meningkatkan dan melatih kesadaran diri dengan penanaman nilai-nilai kedisiplinan, sehingga peserta didik dapat berkembang dengan optimal dengan self awareness.
\end{abstract}

Kata Kunci: self awareness, kedisplinan

\section{Pendahuluan}

Disiplin mengarahkan kegiatan secara teratur, tertib dan rapi, sebab keteraturan ikut menentukan keberhasilan dalam mencapai tujuan belajar. Akan tetapi, meskipun peraturan sudah ditulis namun pada kenyataannya kita sering kali menemukan peserta didik yang masih saja melanggar peraturan yang ada. Masih adanya peserta didik melanggar tata tertib di sekolah seperti datang ke sekolah terlambat, membolos, tidak tertib berseragam maupun berpenampilan, sering tidak mengerjakan tugas-tugas sekolah, tidak tertib mengikuti kegiatan ekstrakurikuler, kurang bisa mengatur waktu belajar di rumah.Hal-hal tersebut sangat menghambat pencapaian tujuan belajar secara maksimal.

Kepala sekolah adalah jabatan pemimpin yang tidak bisa diisi oleh orang-orang tanpa didasarkan atas pertimbangan-pertimbangan. Siapapun yang akandiangkat menjadi kepala sekolah harus ditentukan melalui prosedur serta persyaratan- persyaratan tertentu seperti latar belakang pendidikan, pengalaman, usia, pangkat dan integritas. Kepala sekolah pada hakikatnya adalah pejabat formal sebab pengangakatannya melalui suatu proses dan prosedur yang didasarkan atas peraturan yang erlaku.

Di sekolah, tugas dan tanggung jawab utama guru mata pelajaran (mapel) adalah melaksanakan kegiatan pembelajaran siswa. Kendati demikian, bukan berarti dia sama sekali lepas dengan kegiatan pelayanan bimbingan dan konseling. Peran dan konstribusi guru mapel tetap sangat diharapkan guna kepentingan efektivitas dan efisien pelayanan Bimbingan dan 
Konseling di sekolah. Dalam kedudukannya sebagai personil pelaksana proses pembelajaran di sekolah, guru mapel memiliki posisi yang stretegis, dibandingkan dengan guru pembimbing atau konselor, misalnya, guru mapel lebih sering berinteraksi dengan siswa secara langsung, sehingga dapat mengamati secara rutin perkembangan kepribadian siswa, kemajuan belajarnya, dan bukan tidak mungkin guru mapel akan langsung berhadapan dengan permasalahan siswa.

Guru bimbingan konseling adalah seorang guru yang bertugas memberikan bantuan psikologis dan kemanusiaan secara ilmiah dan professional sehingga seorang guru bimbingan konseling harus berusaha menciptakan komunikasi yang baik dengan murid dalam menghadapi masalah dan tantangan hidup

Agar dapat membantu siswa dalam proses pembelajaran, pendekatan yang digunakan adalah pendekatan pribadi sehingga dapat membantu keseluruhan proses belajarnya. Dalam kaitan ini para pembimbing diharapkan untuk :

a. mengenal dan memahami setiap siswa baik secara individual maupu kelompok,

b. memberikan informasi-informasi yang diperlukan dalam proses belajar,

c. memberi kesempatan yang memadai agar setiap siswa dapat belajar sesuai dengan karakteristik pribadinya,

d. membantu setiap siswa dalam menghadapi masalah-masalah pribadi yang dihadapinya,

e. menilai keberhasilan setiap langkah kegiatan yang telah dilakukan.

Berkenaan dengan hubungan antara bimbingan dan pendidikan tersebut di atas memberikan penjelasan sebagai berikut:

“...bimbingan dan konseling memiliki fungsi dan posisi kunci dalam pendidikan di sekolah, yaitu sebagai pendamping fungsi utama sekolah dalam bidang pengajaran dan perkembangan intelektual siswa dalam bidang menangani ihwal sisi sosial pribadi siswa.."

Lebih lanjut ia menegaskan bahwa bimbingan dan konseling memiliki fungsi memberikan bantuan kepada siswa dalam rangka memperlancar pencapaian tujuan pendidikan, yaitu manusia seutuhnya (tercapainya segala aspek kehidupan manusia).

Pemetaan layanan BK seperti yang tertera pada gambar di atas, menampilkan dengan jelas kesejajaran antara posisi layanan BK yang memandirikan dengan layanan manajemen pendidikan dan layanan pembelajaran yang dibingkai oleh kurikulum khusus sistem persekolahan sebagai bentuk kelembagaan dalam jalur pendidikan formal. Wilayah bimbingan dan konseling yang memandirikan menjadi tanggung jawab konselor.

Pelayanan bimbingan dan konseling dapat memberikan sumbangan yang berarti terhadap pengajaran. Misalnya, siswa dapat mencapai prestasi belajar yang optimal apabila terbebas dari masalah-masalah yang dapat mengganggu proses belajarnya. Pembebasan masalah tersebut dapat dilakukan melalui pelayanan bimbingan dan konseling. Materi layanan bimbingan dan konseling dapat dimanfaatkan oleh guru untuk penyesuaian pengajaran dengan individualitas siswa.

Pelayanan bimbingan dan konseling juga memberikan sumbangan dalam manajemen dan supervisi. Misalnya, berkaitan dengan penyusunan kurikulum, pengembangan programprogram belajar, pengambilan belajar yang tepat dalam rangka penciptaan iklim sekolah yang benar-benar menunjang bagi pemenuhan kebutuhan dan perkembangan siswa. Begitu pula sebaliknya, bidang pengajaran, manajemen, dan supervisi memberikan sumbangan besar bagi pelayanan bimbingan dan konseling. Jika ketiganya berjalan dengan baik, maka akan mencegah timbulnya masalah pada siswa juga sebagai wahana pengentasan masalahmasalah siswa. 
Keberhasilan peserta didik dalam mencapai prestasi belajar, dihubungi oleh beberapa faktor yaitu tingkat kecerdasan yang baik, pelajaran sesuai dengan bakat yang dimiliki, ada minat dan perhatian yang tinggi terhadap pembelajaran, kedisiplinan dalam belajar dan melaksanakan tugas, motivasi yang baik dan strategi pembelajaran yang dikembangkan oleh guru. Suasana keluarga yang mendorong anak untuk maju, selain itu lingkungan sekolah yang tertib, teratur dan disiplin merupakan pendorong dalam proses pencapaian prestasi belajar.

Berdasarkan hasil wawancara informasi dari guru kelas Ibu. Dra.Chandra Kirti, M.M.Pd, dan juga guru BK di SMP Wiyatama Bandar Lampung, terdapat 60 peserta didik dari 120 peserta didik belum sepenuhnya memiliki kedisiplinan terutama di kelas VIII. Hal ini dapat dilihat dari beberapa gejala yang tampak di lapangan diantaranya adalah sering terjadinya pelanggaran tata tertib, seperti terlambat datang ke sekolah, tidak disiplin dalam berseragam, kurang mengetahui cara belajar yang baik yaitu belajar kalau akan menjelang ujian, malas dalam mengerjakan tugas-tugas yang telah diberikan oleh guru, kurang bisa belajar sendiri, tidak dapat membagi waktu untuk belajar, masih adanya paksaan untuk belajar dari guru, sering menyontek hasil pekerjaan temannya, dan mengerjakan tugas pekerjaan rumah saat mengikuti mata pelajaran yang lain yang mengakibatkan proses belajar menjadi terganggu. Hal ini menandakan peserta didik kurang memiliki kedisiplinan, karena ciri-ciri kedisiplinan peserta didik yang telah disebutkan di atas belum tampak pada peserta didik. Apabila keadaan demikian tidak mencapai kedisiplinan dan dikhawatirkan prestasi peserta didik akan menurun, sehingga peserta didiktidak dapat mencapai tujuan yang diharapkan dan keberhasilan belajar tidak dapat dicapai

Sekolah sebagai tempat pendidikan anak perlu dilatih untuk sungguh-sungguh menaati kedisiplinan. Kedisiplinan mendukung kesuksesan dalam belajar. Sekolah tidak sekedar membentuk peserta didik yang pandai tetapi juga membentuk peserta didik yang disiplin. Hal ini akan bermanfaat dan menjadi bekal hidup peserta didik yang teratur.

Dalam kegiatan ini peserta didik diharapkan dapat saling berinteraksi secara dinamis dalam memecahkan suatu permasalahan antar anggota kelompok dengan menyatukan berbagai jawaban/pendapat peserta didik melalui pemikiran-pemikiran, pengetahuan, pergaulan serta ketrampilan berfikir dalam memunculkan gagasan dan ide baru yang nantinya diharapkan akan dapat memberikan pemahaman dalam meningkatkan serta mengembangkan kedisiplinan pada peserta didik tersebutself - awareness membantu peserta didik dalam penanaman disiplin di sekolah. Dengan dipandu guru BK diharapkan peserta didik secara berkelompok dapat lebih memahami dan melaksanakan kedisiplinan sehingga suasana belajar di sekolah akan tercipta dengan baik, peserta didik dapat mengendalikan diri dan dapat bertingkah laku positif.

\section{A. Self awareness}

1. Pengertian self awareness

Self - awareness atau kesadaran diri adalah wawasan kedalam atau wawasan mengenai alasan-alasan dari tingkahlaku sendiri atau pemahaman diri sendiri. Self awarenessatau kesadaran diri dalah bahan baku yang penting untuk menunjukkan kejelasan dan pemahaman tentang perilaku seseorang. Kesadaran diri juga merupakan suatu yang bisa memungkinkan oranglain mampu mengamati dirinya sendiri maupun membedakan dirinya dari dunia (orang lain), serta yang memungkinkan oranglain mampu menempatkan diri dari suatu waktu dan keadaan.

Self-awareness merupakan salah satu bentuk bimbingan yang dilakukan melalui media kelompok dimana metode yang dibahas penyelesaian ditentukan atas kesepakatan seluruh anggota kelompok. Anggota kelompok bebas mengeluarkan pendapat, 
menanggapi, memberi saran tetapi tidak boleh keluar dari materi yang sudah ditentukan oleh pembimbing.

Self-awareness sangat tepat bagi kelompok remaja karena memberikan kesempatan untuk menyampaikan gagasan, perasaan, permasalahan, melepas keragu-raguan diri, dan pada kenyataanya peserta didik akan senang berbagi pengalaman dan keluhan-keluhan pada teman sebayanya.Self awarenessatau kesadaran diri adalah bahan baku yang penting untuk menunjukkan kejelasan dan pemahaman tentang perilaku seseorang. Kesadaran diri juga menjadi titik tolak bagi perkembangan pribadi. Pattonmenyebutkan bahwa kesadaran diri merupakan sifat yang ada pada Emosional Intellegency dan pada titik kesadaran inilah pemgembangan (EQ) dapat dimulai, saluran menuju pada kesadaran diri adalah rasa tanggung jawab dan keberanian.

Dari berbagai pendapat di atas dapat disimpulkan kesadaran diri adalah kemampuan untuk mengenal dan memilah- milah perasaan pada diri, memahami hal yang sedang kita rasakan dan mengapa hal tersebut bisa kitarasakan dan mengetahui penyebab munculnya perasaan tersebut, serta pengaruh perilaku kita terhadap orang lain.

2. Bentuk-Bentuk Self Awareness

Menurut Baron dan Byrne tokoh psikologi sosial, mengatakan bahwaself awarenessmemiliki beberapa bentuk diantaranya: a) Self awarenesssubjektif, b) Self awarenessobjektif, c) Self awarenesssimbolik.

a. Self awarenesssubjektif adalah kemampuan orgasme untuk membedakan dirinya dari lingkungan fisik dan sosialnya. Dalam hal ini serang siswa di sadarkan tentang siapa dirinya dan statusnya yang membedakan dirinya dengan orang lain. Ia harus sadar bahwa siapa dia dimata orang-orang di sekitarnya. Dan bagaimana ia harus bersikap yang membuat orang bisa menilai siswa tersebut bisa berbeda dengan yang lainnya.

b. Self awarenessobjektif adalah kapasitas orgasme untuk menjadi objek perhatiannya sendiri, kesadaran akan keadaan pikirannya dan mengetahui bahwa bahwa ia tahu dan mengingat bahwa ia ingat. Hal ini berkaitan dengan identitas siswa sendiri sebgai seorang pelajar. Kalau siswa ingat bahwa ia adalah seorang murid, ia akan memfokuskan dirinya dan menempatkan dirinya pula sebagai siswa. Dan mengingat berbagai bentuk hak dan kewajiban yang menjadi tangung jawabnya.

c. Self awarenesssimbolik adalah kemampuan organisme untuk membentuk sebuah konsep abstrak dari diri melalui bahasa kemampuan ini membuat organisme mampu untuk berkomunikas, menjalin hubungan, menentukan tujuan mengevaluasi hasil dan membangun sikap yang berhubungan dengan diri dan membelanya terhadap komunikasi yang mengancam. Siswa dalam hal ini lebih di tekankan untuk bisa mengenali dirinya dan harus bisa berfikir jauh tentang dirinya di mata orang lain, siswa dalam hal ini lebih banyak belajar dari sekitarnya, dan lebih penting siswa harus bisa belajar bagaimana bisa menyampaikan sesutau dengan baik kepada orang lain lewat sebuah komunikasi yang baik agar siswa bisa membentuk sebuah hubungan dengan orang lain.

\section{Karakteristik Dalam Pembentukan Self Awareness}

Menurut Charlesdalam membentukself-awarenes dalam diri seseorang dibutuhkan sebuah kerangka kerjayang terdiri dari lima elemen primer, diantaranya: a) Attention (atensiperhatian), b) Wakefulness (kesiagaan/kesadaran), c) Architecture (Arsitektur), d) Architecture (Arsitektur), e) Recall of knowledge

(mengingat pengetahuan), f) Self knowledge (pengetahuan diri). 
a. Attention (atensiperhatian) adalah pemusatan sumber daya mental ke hal- hal eksternal maupun ienternal. Kita dapat mengarahkan atensi kita ke peristiwa-peristiwa eksteral maupun internal, dan oleh sebab itu, kesadaran pun dapat kita arahkan ke peristiwa eksternal dan internal.

b. Wakefulness (kesiagaan/kesadaran) adalah kontinum dari tidur hingga terjaga. Kesadaran, sebagai suatau kondisi kesiagaan memiliki komponen arousal. Dalam bagiankerangka kerja awareness ini, kesadaran adalah suatu kondisi mental yang dialami seseorang sepanjang kehidupnya. Kesadaran terdiri berbagai level awareness dan esksetasi yang berbeda, dan kita bisa mengubah kondisi kesadaran kita mengunakan berbagai hal.

c. Architecture (Arsitektur) adalah lokasi fisik struktur fisiologis dan proses-proses yang berhubungan dengan struktur tersebut yang menyongkong kesadaran. Sebuah konsep dari definitive dari kesadaran adalah bahwa kesadaran memiliki sejumlah struktur fisiologis (suatu struktur arsitektural). Diasumsikan bahwa kesadaran berpusat di otak dan dapat di definisikan melalui penyelidikan terhadap korelasi naural kesadaran di otak dan dapat diidentifikasikan melalui penyelidikan terhadap korelasi neural kesadaran.

d. Recall of knowledge (mengingat pengetahuan) Adalah proses pengambilan informasi tentang pribadi yang bersangkutan dengan dunia sekelilingnya.

e. Self knowledge (pengetahuan diri) adalah pemahaman tentang informasi jati diri pribadi seseorang. Pertama, terdapat pengetahuan fundamental bahwa anda adalah anda.

B. Kedisiplinan

1. Pengertian Kedisiplinan

Kata disiplin dalam bahsa inggris di sebut dengan discipline, berasal dari akar kata bahsa litin yang sama (discipulus) dengan katadisciple dan mempunyai makna yang sama: megajari atau mengikuti pemimpin yang dihormati. Kedisiplinan berasal dari kata dasar disiplin yang kemudian mendapat awalan ke- dan akhiran -an. Dalam kamus bahasa disiplin mempunyai arti ketaan dan kepatuhan kepada peraturan, tata tertib dan sebagainya. Disiplin adalah kekuatan yang menuntut kepada anak didik untuk mentaatinya. Yang di dalamnya ada kekuasaan dalam norma yang mengikat untuk ditaati di kelas.Disiplin adalah sikap kesediaan dan kerelaan seseorang untuk mematuhi dan mentaati norma-norma peraturan yang berlaku di sekitarnya.Sedangkan menurut Abdurahman Assegaf, bahwa disiplin adalah suatu kondisi yang tercipta dan terbentuk melalui proses dari serangkaian perilaku yang menunjukkan nilai-nilai ketaatan, kepatuhan, kesetiaan, keteraturan dan atau ketertiban.Disiplin artinya adalah ketaatan (kepatuhan) kepada peraturan, tata tertib, aturan, atau norma dan lain sebagainya.

Menurut Allenbahwa ada dua pengertian pokok tentang disiplin yaitu : (1) proses atau hasil pengembangan karakter, pengendalian diri, keadaan teratur dan efisien. Ini adalah jenis disiplin yang disebut disiplin positif atau disiplin konstruktif, (2) penggunaan hukuman atau ancaman hukuman untuk membuat orang-orang mematuhi perintah dan mengikuti peraturan dan hukum. Jenis disiplin ini telah diberi macam-macam nama : disiplin negatif, disiplin otoriter, disiplin menghukum atau menguasai melalui rasa takut.Menurut Al- Ghozali disiplin diartikan sebagai kesediaan untuk mematuhi peraturan, bukan hanya patuh karena adanya tekanan dari luar, melainkan kepatuhan didasari oleh adanya kesadaran tentang nilai dan pentingnya peraturan itu.

Dari beberapa pendapat para ahli di atas disimpulkan bahwa kedisiplinan adalah ketaatan atau kepatuhan kepada peraturan, tata tertib, aturan, norma yang berlaku.Kedisiplinan siswa dapat dilihat dari ketaatan siswa terhadap peraturan (tata 
tertib) yang berlaku di sekolah yang meliputi jam masuk sekolah dan keluar sekolah, kepatuhan siswa dalam berpakaian dan semua yang berkaitan dengan kehidupan di lingkungan sekolah.

2. Tujuan Kedisiplinan

Tujuan kedisiplinan adalah :

a. Memberi dukungan bagi terciptanya perilaku yang tidak menyimpang

b. Mendorong siswa melakukan yang baik dan benar

c. Membantu siswa memahami dan menyesuaikan diri dengan tuntutan lingkungannya dan menjauhi melakukan hal-hal yang dilarang oleh sekolah, dan

d. Siswa belajar hidup dengan kebiasaan-kebiasaan yang baik dan

e. bermanfaat baginya serta lingkungannya.

Tujuan disiplin menurut Schaefer Charles dibagi menjadi dua yaitu :

1) Tujuan jangka pendek disiplin adalah membuat anak-anak terlatih dan terkontrol dengan mengajarkan mereka bentuk-bentuk tingkah laku yang tidak pantas atau yang masih asing bagi mereka.

2) Tujuan jangka panjang disiplin adalah untuk perkembangan pengendalian diri (self control and self direction), yaitu dalam hal apa anak-anak dapat mengarahkan diri sendiri tanpa pengaruh pengendalian dari luar. Pengendalian diri berarti menguasai tingkah laku sendiri dengan berpedoman pada norma- norma yang jelas, standarstandar dan aturan -aturan yang menj adi miliknya sendiri.

Untuk menanamkan kedisiplina pada anak bertujuan untuk menolong anak memperoleh keseimbangan antara kebutuhan untuk berdikari dan penghargaan terhadap hakhak orang lain. Dari beberapa pendapat para ahli di atas dapat mengambil kesimpulan bahwa tujuan kedisiplinan adalah melatih siswa agar dapat mengatur dirinya sendiri, percaya pada diri sendiri serta dapat mengendalikan diri.

3. Bentuk-bentuk Kedisiplinan

Menurut Winkel W.S. dan Sri Hastuti, Bentuk- bentuk kedisiplinan adalah:

a. Hadir di ruang kelas pada waktunya.

Kedisiplinan hadir di ruang kelas pada waktunya akan memacu kesuksesan dalam belajar. Peserta didik yang sering terlambat hadir di ruang kelas akan ketinggalan dalam memperoleh pelajaran, tidak akan mencapai kesuksesan atau keberhasilan dengan baik dalam belajar.

b. Menaati tata pergaulan di sekolah

Sikap untuk disiplin dalam tata pergaulan di sekolah ini bisa diwujudkan dengan tindakan-tindakan menghormati semua orang yang tergabung dalam sekolah, menghormati pendapat mereka, menjaga diri dari perbuatan dan sikap yang bertentangan dengan agama, saling tolong menolong dalam hal terpuji serta harus selalu bersikap terpuji.

c. Mengikuti kegiatan ekstrakurikuler

Kegiatan ekstrakurikuler adalah juga merupakan serentetan program sekolah, maka peserta didik juga dituntut berdisiplin atau aktif mengikutinya dengan mencurahkan segala potensi yang mereka miliki baik yang bersifat fisik, mental, emosional dan intelektual. Kegiatan ekstrakurikuler adalah kegiatan yang dilakukan di luar jam terjadwal dan bertujuan untuk memperluaspengetahuan siswa, mendorong pembinaan nilai dan sikap serta memungkinkan penerapan lebih lanjut pengetahuan yang telah dipelajari dari berbagai mata pelajaran dalam kurikulum. 
d. Belajar di rumah

Dengan kedisiplinan belajar di rumah peserta didik menjadi lebih ingat terhadap pelajaran yang telah dipelajari dan lebih siap untuk menghadapi.

Menurut Suharsimi Arikunto, bentuk-bentuk disiplin meliputi :

a. Disiplin dalam mengikuti pelajaran, disiplin merupakan suatu masalah penting. Tanpa adanya kesadaran akan keharusan melaksanakan aturan yang sudah ditentukan sebelumnya, pengajaran tidak akan mencapai target maksimal.

b. Disiplin lingkungan, semua siswa diberi kesempatan untuk melakukan apa yang dikehendaki dalam lingkungannya dengan memperhatikan peraturan dan manfaat dari kegiatan yang dilakukan sehingga siswa dapat menentukan suatu perilaku yang berarti bagi dirinya.

Dari pendapat di atas maka dapat disimpulkan bentuk disiplin siswa, adalah disiplin dapat mentaati waktu, disiplin dalam berpakaian dan disiplin dalam

belajar di sekolah, dalam tata pergaulan di sekolah baik sesama siswa maupun dengan guru dan staf yang ada di sekolah.

4. Manfaat Kedisiplinan

Manfaat disiplin adalah membuat siswa menjadi lebih tertib dan teratur dalam menjalankan kehidupannya serta siswa juga mengerti bahwa kedisiplinan itu amat sangat penting bagi masa depannya kelak, karena dapat membangun kepribadian siswa yang kokoh dan bisa diharapkan berguna bagi semua pihak.

a. Menata kehidupan bersama

Manusia adalah mahluk yang memiliki ciri, sifat, kepribadian, latar belakang dan pola pikir yang berbeda- beda. Selain sebagai mahluk individu juga sebagai mahluk sosial yang selalu berhubungan dengan orang lain.Dalam hubungan tersebut diperlukan adanya norma, nilai dan peraturan untuk mengatur agar kehidupan dan kegiatannya dapat berjalan lancar dan baik.

b. Membangun kepribadian

Pertumbuhan kepribadian seseorang biasanya dipengaruhi oleh faktor lingkungan keluarga, lingkungan pergaulan, lingkungan masyarakat dan lingkungan sekolah. Oleh karena itu dengan disiplin, seseorang dibiasakan mengikuti, mematuhi dan menaati peraturan-peraturan yang berlaku. Lingkungan yang berdisiplin baik, sangat berpengaruh terhadap kepribadian seseorang. Apalagi seorang siswa yang sedang tumbuh kepribadiannya, tentulingkungan sekolah yang tenang dan tentram sangat berperan dalam membangun kepribadian yang baik.

c. Melatih kepribadian

Sikap perilaku dan pola kehidupan yang baik dan berdisiplin tidak terbentuk serta merta dalam waktu yang singkat, namun terbentuk dari suatu proses yang membutuhkan waktu yang panjang dan terus dilakukan latihan, pembiasaan diri mencoba, berusaha dengan gigih bahkan disertai dengan tempaan yang keras. siswa untuk menaati dan mematuhinya. Tanpa ancaman hukuman atau sanksi, dorongan ketaatan dan kepatuhan dapat melemah.

d. Mencipta lingkungan kondusif

Peraturan sekolah yang dirancang dan di implementasikan dengan baik memberi pengaruh bagi terciptanya sekolah sebagai lingkungan pendidikan yang kondusif untuk kegiatan belajar. Tanpa ketertiban, suasana kondusif bagi pembelajaran akan terganggu sehingga akan menghambat proses pencapaian prestasi belajar. 
Manfaat disiplin adalah:

1. Berguna untuk merencanakan kesuksesan, sudah banyak contoh orang yang berhasil karena disiplin

2. Membentuk diri memiliki pribadi yang unggul

3. Menjadi pribadi yang seimbang dan dapat mengontrol diri sendiri untuk mengikuti keinginan pribadi dan orang lain

4. Menghindarkan diri dari perbuatan yang tidak benar, 5.Memberikan kenyamanan bagi orang lain

Dalam mencapai suatu prestasi, siswa harus memiliki rasa disiplin yang tinggi khususnya disiplin individu yang dimulai dalam lingkungan kecil yaitu keluarga dan dibawa ke lingkungan yang lebih besar yaitu sekolah. Disiplin individu hams dilatih terns menems yang pada akhirnya menjadi kebiasaan bukan suatu paksaan sehingga dapat memperlancar dalam mencapai suatu prestasi dan menuju kearah sikap yang lebih baik.

5. Faktor yang Mempengaruhi Kedisiplinan

Faktor-faktor yang mempengaruhi disiplin:

a. Dorongan yang datangnya dari dalam diri manusia yaitu; pengetahuan, kesadaran dan kemauan untuk berbuat disiplin.

b. Dorongan yang datangnya dari luar yaitu perintah, larangan, pengawasan, pujian, ancaman, hukuman dan sebagainya.

Faktor - faktor yangmempengaruhi disiplin :

a. Diri sendiri

Pelaksanaan disiplin ini berdasarkan dari dalam diri siswa. Karena tanpa sikap kesadaran dari diri sendiri, maka apapun usaha yang dilakukan oleh orang disekitarnya hanya akan sia-sia.

b. Keluarga

Keluarga adalah tempat latihan dan penerapan disiplin yang pertama dan utama. Dasar pendidikan disiplin dalam keluarga sangat mempengaruhi perkembangan kepribadian selanjutnya.

c. Pergaulan lingkungan

Lingkungan mempunyai andil yang besar dalam penerapan disiplinbaik itu lingkungan sekolah maupun lingkungan masyarakat.Dimana apabila seseorang masuk dalam lingkungan yangmenerapkan disiplin atau sebaliknya masuk dalam lingkunganyang tidak baik akan membentuk kepribadian seseorang danberpengaruh pada perkembangan selanjutnya.

Dari pendapat para ahli di atas maka penulis dapat membuatkesimpulan bahwa faktor yang mempengaruhi kedisiplinan bisa berasaldari diri sendiri maupun dari luar diri sendiri baik itu dari lingkungansekolah, keluarga, maupun lingkungan pergaulan seseorang di masyarakat.

6. Sanksi Peraturan Tata-Tertib Sekolah

a. Diperingatkan secara lisan

b. Tiga kali peringatan lisan, dilakukan peringatan tertulis dengan tembusan orang tua.

c. Tidak boleh mengikuti pelajaran tertentu dan hal-hal lain yang ditetapkan oleh pihak sekolah.

d. Diskor (diberhentikan sementara)

e. Diserahkan kembali kepada orang tua 


\section{Metode Penelitian}

Untuk mengetahui hubungan self - awarenessdengan kedisiplinan peserta didik kelas VIII di SMP Wiyatama Bandar Lampung, sesuai dengan butir rumusan masalah, tujuan dan kegunaan penelitian, maka digunakan metode penelitian kuantitatif korelasional. Penelitian kuantitatif korelasional adalah penelitian ilmiah yang sistematis terhadap bagian- bagian dan fenomena serta hubungan- hubungannya. Tujuan penelitian kuantitatif korelasional adalah mengembangkan dan menggunakan model-model matematis, teori-teori dan/atau hipotesis yang berkaitan dengan fenomena alam. Proses pengukuran adalah bagian yang sentral dalam penelitian kuantitatif korelasional karena hal ini memberikan hubungan yang fundamental antara pengamatan empiris dan ekspresi matematis dari hubungan-hubungan kuantitatif korelasional.

\section{Hasil dan Pembahasan}

A. Gambaran Umum SMP Wiyatama Bandar Lampung

1. Sejarah singkat SMP Wiyatama Bandar Lampung

Yayasan Pendidikan Wiyatama merupakan suatu lembaga non pemerintah yang mengelola bidang pendidikan. Yayasan Pendidikan Wiyatama saat ini mengelola 1(satu) sekolah yaitu Sekolah Menengah Pertama (SMP).

Pendiri Yayasan Pendidikan Wiyatama adalah :
a) Drs. Hi. Subadi
b) Sunarto, DS
c) Walyudi, S.Ip
d) Darwin

Selain itu dibantu oleh simpatisan yang turut mendukung berdirinya Yayasan Pendidikan Wiyatama yaitu :

a) Sudarmo, Msc

b) Hj. Kusmiyati, S.Pd

c) Zm. Nainggolan

Berdirinya Yayasan Pendidikan Wiyatama pada tanggal 17 Agustus 1985 berdasarkan akta notaris No. 85/64/1985, untuk pertama kalinya Yayasan Pendidikan Wiyatama mengelola/mendirikan SMP Wiyatama.

SMP Wiyatama mulai menyelenggarakan proses belajar pada tahun 1985/1986, dengan operasional dari menteri Pendidikan \& Kebudayaan Republik Indonesia No.

1106/I.12.BI/U1989. Selanjutnya untuk memimpin jalannya pendidikan dan pengajaran maka diangkatlah seorang kepala sekolah yaitu Bapak Sunarto, DS sebagai kepala sekolah pertama dari tahun 1985s/d 2002. Pada tahun 2002 sebagai kepala sekolah kedua diangkatlah Ibu Dra.Candra Kirti, M.M.Pd.

SMP Wiyatama dengan jelas bernaung dibawah Yayasan Pendidikan Wiyatama hingga segala kebijaksanaan dalam menjalankan roda pendidikan dan pengajaran harus selalu merujuk kepada aturan dan kebijakan Yayasan Pendidikan Wiyatama yang kepengurusannya sebagai berikut :

a) Penasehat : Sudarmo, Msc

b) Ketua : Drs. Hi. Subadi

c) Sekertaris : Walyudi, S.Ip

d) Bendahara : Hj. Kusmiyati, S.Pd

e) Anggota: Kamini, Edi Nainggolan, Sri Sulastri 
Dibawah pembinaan para pengurus Yayasan Pendidikan Wiyatama, maka kebijaksanaan sekolah ditetapkan serta turut membantu pengelolaan sekolah untuk mewujudkan keberhasilan pendidikan yang diinginkan.

Saat ini SMP Wiyatama memiliki status Terakreditasi (B) berdasarkan keputusan Badan Akreditasi Sekolah Bandar Lampung No. 12.09. Dp.009.06 tanggal 8 Maret 2006. SMP Wiyatama memiliki :

a) Nomor Statistik Sekolah (NSS): 202126004066

b) Nomor Identitas Sekolah (NIS): 200660

c) Nomor Pokok Nasional Sekolah (NPSN): 10807156

SMP Wiyatama terletak didesa Podoharjo Sgalamider tepatnya di Jl. Panglima Polim Gg. Sawo No. 37. Lokasinya sangat strategis dari segi pendidikan karena cukup mudah menjangkau lokasi tersebut, sehingga cukup menarik untuk peserta didik disekolah tersebut. Luas lokasi yang dimili 1.460 meter persegi dan luas bangunan 672 meter persegi, batasbatas SMP Wiyatama :

a) Sebelah timur berbatasan dengan SMP 10 Bandar Lampung

b) Sebelah utara berbatasan dengan rumah penduduk

c) Sebelah selatan berbatasan dengan PGSD

d) Sebelah barat berbatasan dengan rumah penduduk.

2. Analisis Data dan Pengujian Hipotesis

Analisis data dalam penelitian merupakan suatu hal yang sangat penting untuk dilakukan. Data yang telah terkumpul melalui penelitian belum memberikan apa-apa sebagaimana menjadi harapan dalam penelitian. Menurut Sugiyono analisis data merupakan kegiatan setelah data dari seluruh responden atau sumber data lain terkumpul. Kegiatan utama dalam analisis data adalah melakukan perhitungan untuk menjawab rumusan masalah, dan melakukan perhitungan untuk menguji hipotesis yang telah diajukan.

Pengujian ini untuk mengetahui apakah sebaran data indikator kedisiplinan dengan indikator self awareness tersebut berdistribusi normal atau tidak, maka dilakukan uji normalitas dengan menggunakan statistic nonparametris. Hasil uji normalitas dengan menggunakan SPSS 23 dapat dijelaskan pada table 1 sebagai berikut :

Tabel 1. Hasil Uji Normalitas Test of Normality Tests of Normality

\begin{tabular}{cccc}
\hline & \multicolumn{3}{c}{ Kolmogorov-Smirnova } \\
\hline & Statistic & df & Sig. \\
\hline $\begin{array}{c}\text { Self } \\
\text { Awareness }\end{array}$ & 0,101 & 60 &, $200 *$ \\
\hline Kedisiplinan & 0,115 & 60 & 0,048 \\
\hline
\end{tabular}

Dari table 1 dapat dijelaskan bahwa data yang didistribusikan normal dapat dilihat dari kolom signifikasi (sig) dengan ketentuan dikatakan normal jika sig bernilai $\geq 0,05$ dan tidak dikatakan normal jika mean bernilai $<0,05$. Dari data tersebut untuk mengetahui kenormalan distribusi data maka digunakan uji kolmogrov smirnov dengan keterangan sama dengan uji non parametrik dengan nilai signifikan untuk variable sebagai berikut :

a. Indikator Kedisiplinan : 200

b. Indikator Self Awareness : 48

Nilai probalitas atas nilai sig yang didapat dari angket self awareness $\geq 0,05$ maka data-data tersebut berdistribusi normal. 
Uji Homogenitas digunakan untuk mengetahui apakah kedua indikator memiliki karakter yang sama atau tidak. Uji Homogenitas varian dilakukan pada variabel kedisiplinandan self awareness. Adapun uji homogenitas dapat dilihat pada tabel 4.5 sebagai berikut :

Tabel 2. Test of Homogeneity of Variances

\begin{tabular}{cccc}
\hline Levene & df1 & df2 & Sig. \\
\hline 1,287 & 8 & 51 & 0,271 \\
\hline
\end{tabular}

Dari tabel 2 dapat dijelaskan bahwa nilai Levene Statistic adalah 1,287 dengan nilai probalitas atau sig >0,05 yaitu 0,271 maka varian sampel dikatakan homogeny. Dikatakan homogeny jika nilai signifikasi (sig) > 0,05 dan jika data pada Levene Statisticbernilai signifikasi (sig) $<0,05$ maka data dinyatakan tidak homogen.

Analisis Unvariat digunakan presentase hasil dari setiap variabel ditampilkan dalam bentuk distribusi frekuensi. Dalam perhitungan menggunakan program computer.

a. Self Awareness Peserta Didik Di SMP Wiyatama Bandar Lampung

Data mengenaiself swareness yang berhasil disimpulkan dari sampel sebanyak 60 peserta didik secara kuantitatif menunjukan bahwa skor tertinggi adalah 75 dan terendah adalah 15. Hasil analisis disajikan dalam bentuk tabel frekuensi sebagai berikut :

Tabel 3 Distribusi Frekuensi Self Awareness

\begin{tabular}{cccc}
\hline \multirow{2}{*}{ Skor } & \multirow{2}{*}{ Kriteria } & \multicolumn{2}{c}{ Frekuensi } \\
\cline { 3 - 4 } & & F & \% \\
\hline$<38$ & Tertutup & 25 & 41,7 \\
\hline$\geq 38$ & Terbuka & 35 & 58,3 \\
\hline
\end{tabular}

Dalam tabel 4 dijelaskan bahwa tingkat self awareness peserta didik di SMP Wiyatama Bandar Lampung tertutup yaitu sebesar 41,7\% dan yang terbuka sebesar 58,3\% seperti halnya telah dijelaskan dalam tabel 4.6 bahwa peserta didik yang memiliki self awarenessyang terbuka terdapat 25 peserta didik dan self awarenesstertutup terdapat 35 peserta didik dengan begitu self awarenesstelah dimiliki oleh peserta didik dan terdapat sebagian kecil self awarenessyang tertutup.

b. Kedisiplinan Peserta Didik Di SMP Wiyatama Bandar Lampung

Data mengenai kedisiplinan yang berhasil disimpulkan dari sampel sebanyak 60 peserta didik secara kuantitatif menunjukan bahwa skor tertinggi adalah 14 dan terendah adalah 0 . Hasil analisis disajikan dalam bentuk tabel frekuensi sebagai berikut :

Tabel 4. Distribusi Frekuensi Kedisiplinan

\begin{tabular}{cccc}
\hline \multirow{2}{*}{ Skor } & \multirow{2}{*}{ Kriteria } & \multicolumn{2}{c}{ Frekuensi } \\
\cline { 3 - 4 } & F & \% \\
\hline$\leq 7$ & Disiplin & 47 & 78,3 \\
\hline$>7$ & $\begin{array}{c}\text { Tidak } \\
\text { Disiplin }\end{array}$ & 13 & 21,7 \\
\hline
\end{tabular}

Dalam tabel 4 dijelaskan bahwa tingkat kedisiplinan peserta didik di SMP Wiyatama Bandar Lampung disiplin yaitu sebesar 78,3\% dan yang tidak disiplin sebesar 21,7\% seperti 
halnya telah dijelaskan dalam tabel 4.7 bahwa peserta didik yang memiliki kedisiplinan yang disiplin terdapat 47 peserta didik dan kedisiplinantidak disiplin terdapat 13 peserta didik dengan begitu kedisiplinan telah dimiliki oleh peserta didik dan terdapat sebagian kecil kedisiplinan tidak disiplin.

3. Hasil Analisis Bivariat

Analisa bivariat merupakan rancangan yang bertujuan untuk mendeskripsikan hubungan antara dua variable. Dalam penelitian ini peneliti menggunakan SPSS 23 untuk menguji data yang diperoleh dan berikut hasil uji yang diperoleh:

Tabel 5. Hasil Uji Korelasi

\begin{tabular}{|c|c|c|c|}
\hline \multicolumn{4}{|c|}{ Correlations } \\
\hline & & disiplin & \\
\hline \multirow[t]{3}{*}{ Kedisiplinan } & $\begin{array}{c}\text { Pearson } \\
\text { Correlation }\end{array}$ & 1 &,$- 387 * *$ \\
\hline & Sig. (2-tailed) & & .002 \\
\hline & $\mathrm{N}$ & 60 & 60 \\
\hline \multirow[t]{3}{*}{$\begin{array}{c}\text { Self } \\
\text { Awareness }\end{array}$} & $\begin{array}{c}\text { Pearson } \\
\text { Correlation }\end{array}$ &,$- 387 * *$ & 1 \\
\hline & Sig. (2-tailed) & .002 & \\
\hline & $\mathrm{N}$ & 60 & 60 \\
\hline
\end{tabular}

Berdasarkan hasil uji yang dijelaskan pada table 5 bahwa p-value $=0.002$ yang berarti $\rho<\alpha$. Hal ini menunjukan menolak Ho dan menerima Ha. Maka peneliti dapat menyimpulkan bahwa terdapat hubungan yang positif dan signifikan antara kedisiplinan dengan self awareness peserta didik di SMP Wiyatama Bandar Lampung.

4. Pengujian Hipotesis

Hipotesis yang peneliti peroleh adalah sebagai berikut :

Ha: Adanya hubungan antara self awareness dengan kedisiplinan peserta didik di SMP Wiyatama Bandar Lampung tahun pelajaran 2015/2016.

Ho: Tidak adanya hubungan self awareness dengan kedisiplinan peserta didik di SMP Wiyatama Bandar Lampung tahun pelajaran 2015/2016.

Hipotesis Statistik

Ho : $\rho=0,0$ berarti tidak ada hubungan

Ha : $\rho \neq 0$, " tidak sama dengan nol” berarti lebih besar atau lebih kurang (-) dari nol berarti ada hubungan.

Pada penelitian ini memilih responden yang memiliki tingkat Sekolah Menengah Pertama (SMP) dikarenakan pada masa tersebut merupakan masa transisi yang memiliki tantangan sosial, perubahan kehidupan dan tak pernah lepas dari sebuah masalah bahkan pada masa ini anak bisa saja bersikap anti sosial dan menutup diri sehingga rendahnya kesadaran diri untuk menyadari pentingnya kedisiplinan.

1. Kedisiplinan

Kedisiplinan yang terjadi pada responden dapat diketahui dengan memberikan angket kepada responden,dari angket yang telah diberikan kepada responden maka tingkat kedisiplinan dapat dijabarkan pada table 4.6 dalam table tersebut diketahui dari 60 peserta didik yang dijadikan sampel dalam penelitian ini, terdapat 13 peserta didik yang berada 
pada kelompok tidak disiplin dari perhitungan persentase sebesar $21,7 \%$ dan terdapat 47 peserta didik yang memiliki sikap disiplin dari persentase sebesar 78,3\%. Dengan begitu masalah kedisiplinan sudah cukup baik pada peserta didik di SMP Wiyatama Bandar Lampung.

Dengan begitu peneliti dapat menyimpulkan bahwa sikap disiplin masih dimiliki peserta didik SMP Wiyatama Bandar Lampung. Hal ini dapat dibuktikan oleh hasil penelitian yang menunjukan bahwa peserta didik yang tergolong disiplin dengan perincian item subjek yang menjawab setuju/yaberjumlah 47 peserta didik dengan persentase sebesar 78,3\%.

Kedisiplinan adalah kekuatan yang menuntut kepada anak didik untuk mentaatinya. Yang di dalamnya ada kekuasaan dalam norma yang mengikat untuk ditaati di kelas. Serta sikap kesediaan dan kerelaan seseorang untuk mematuhi dan mentaati norma-norma peraturan yang berlaku di sekitarnya. Seperti halnya dijelaskan oleh Abdurahman Assegaf, bahwa disiplin adalah suatu kondisi yang tercipta dan terbentuk melalui proses dari serangkaian perilaku yang menunjukkan nilai-nilai ketaatan, kepatuhan, kesetiaan, keteraturan dan atau ketertiban.

2. Self-Awareness

Self - awareness yang terjadi pada responden dapat diketahui dengan memberikan angket kepada responden,dari angket yang telah diberikan kepada responden maka tingkat kedisiplinan dapat dijabarkan pada table 4.7 dalam table tersebut tanggapan peserta didik terhadap variabel self awarenessdari 60 peserta didik yang dijadikan sampel dalam penelitian ini, terdapat 25 peserta didik yang memiliki self awareness tertutup dari perhitungan persentase sebesar $41,7 \%$ dan terdapat 35 peserta didik yang self awarenessterbuka dari persentase sebesar $58,3 \%$.

3. Hubungan self awareness dengan kedisiplinan

Berdasarkan hasil analisis data yangtelah di peroleh peneliti bahwa $r$ hitung $>r$ tabledan berdasarkan hasil ujiyang di jelaskan pada table 4.8 bahwa $p$-value $=0,002$ yang berarti $\mathrm{p}<\alpha$ atau telah ditemukan adanya hubungan. Adanya hubungan yang signitifikan antara self awareness dengan kedisiplinan di SMP Wiyatama Bandar Lampung kelas VIII. Hal ini terbukti dari hasil analisis data yang menunjukan yang berarti hipotesis diterima.

Abdurohman dalam bukunya psikologi pendidikan tampa kekerasan yang menjelaskan bahwa sikap disiplin peserta didik juga berhubungan dengan kesadaran diri dalam diri peserta didik (self awareness), peserta didik dinilai baik dalam belajar apabila mereka melaksanakan secara sadar dan terus menerus hal-hal yang telah ditetapkan atau telah di programkan oleh sekolah.

Self - awareness atau kesadaran diriadalah wawasan kedalam atau wawasan mengenai alasan-alasan dari tingkahlaku sendiri atau pemahaman diri sendiri. Self - awareness atau kesadaran diri dalah bahan baku yang penting untuk menunjukkan kejelasan dan pemahaman tentang perilaku seseorang. Kesadaran diri juga merupakan suatu yang bisa memungkinkan oranglain mampu mengamati dirinya sendiri maupun membedakan dirinya dari dunia (orang lain), serta yang memungkinkan oranglain mampu menempatkan diri dari suatu waktu dan keadaan.

Dengan begitu dapat dipahami antara kesadaran diri (self awareness) memiliki hubungan yang seperti di jelaskan oleh Abdurahman dalam bukunya "psikologi pendidikan tanpa kekerasan" bahwa sikap disiplin peserta didik juga berhubungan dengan kesadaran diri dalam diri peserta didik hal ini dibuktikan dengan nilai $p=0,005<0,05$ yang berati ada hubungan yang signitifikan antara kesadaran diri (self awareness) dengan kedisiplinan peserta didik.

Dengan begitu peneliti dapat menyimpulkan bahwa kesadaran diri (self awareness) peserta didik masih dimiliki peserta didik SMP Wiyatama Bandar Lampung. Hal ini dijelaskan pada tabel 4.6 dan 4.7. Pada tabel 4.6 menujukan bahwa peserta didik yang tergolong memiliki 
kesadaran diri tertutup memiliki persentase sebesar $41,7 \%$ dan yang terbuka sebesar 58,3\%.Lalu di tabel 4.7 menunjukan peserta didik yang disiplin memiliki persentase 78,3\% dan yang tidak disiplin $21,7 \%$ yang membuktikan kedisipinan pada peserta didik kelas VIII di SMP Wiyatama Bandar Lampung. Selain itu, data tersebut juga membuktikan bahwa kedua variable antara kesadaran diri (self awareness) dengan kedisiplinan memiliki hubungan yang signitifikan

\section{Simpulan dan Saran}

Dilihat dari hasil penelitian, peneliti dapat menyimpulkan bahwa sikap disiplin masih dimiliki peserta didik SMP Wiyatama Bandar Lampung. Hal ini dapat dibuktikan oleh hasil penelitian menujukan bahwa peserta didik yang tergolong memiliki kesadaran diri (self awareness) tertutup memiliki persentase sebesar $41,7 \%$ dan yang terbuka sebesar 58,3\%. Lalu peserta didik yang disiplin memiliki persentase $78,3 \%$ dan yang tidak disiplin $21,7 \%$ yang membuktikan kedisipinan pada peserta didik kelas VIII di SMP Wiyatama Bandar Lampung. Selain itu, data tersebut juga membuktikan bahwa kedua variable antara kesadaran diri (self awareness) dengan kedisiplinan memiliki hubungan yang signitifikan $(p$-value $=0,002$ yang berarti $\mathrm{p}<\alpha)$.

Berdasarkan penelitian yang telah dilakukan, maka peneliti dapat memberikan beberapa saran danrekomendasi dari hasil penelitian diantaranya:

1. Hasil penelitian ini diharapkan dapat membantu program sekolah dalam usaha mendisiplinkan peserta didik, dan di harapkan dapat di gunakan sebagai referensi bagi sekolah untuk dapat memberikan sarana dan prasarana yang belum diperoleh oleh peserta didik khususnya layanan bimbingan dan konseling guna untuk meningkatkan kedisiplinan melalui kesadaran diri (self awareness). Peneliti menyarankan agar pihak guru kelas dapat bekerjasama membantu peserta didik dalam meningkatkan dan melatih kesadaran diri dengan penanaman nilai-nilai kedisiplinan sehingga peserta didik dapat berkembang dengan optimal, melaui self awareness.

2. Diharapkan dapat membantu guru pembimbing dalam melaksanakan program bimbingan khusus nya hubungan self awareness dalam usaha membantu sekolah menanamkan nilai- nilai kedisiplinan peserta didik. Diharapkan dapat meningkatkan kedisiplinan sehingga memiliki kesadaran diri yang tinggi, unggul, kreatif dan bertanggung jawab.

3. Bagi peneliti selanjutnya peneliti memberi saran agar dapat menambah jumlah repsonden yang dijadikan sampel dari peneliti yang telah dilakukan, serta menambah dan melengkapi teori yang belum ada dari beberapa refrensi lain.

\section{Daftar Pustaka}

Abdurahman. 2004. Psikologi Pendidikan Tanpa Kekerasan Yogyakarta Tiara Wacana.

Ahmad, Abu. 1999. Bimbingan dan Konseling di Sekolah. Jakarta : Rineka Cipta

Allen, Jane Elisabeth. 2005. Disiplin Positif (Menciptakan Dunia Penitipan Anak yang Edukatif Bagi Anak Pra-Sekolah), Jakarta: Anak Prestasi Pustaka.

Andi hakim nasution. 2002. Pendidikan Agama dan Akhlak bagi Anak dan remaja cet 1. Ciputat: Logos Wacana Ilmu.

Arsip SMP Wiyatama Bandar Lampung, tahun. 2014.

Assegaf, Abdurrahman. 2004. Pendidikan Tanpa Kekerasan, Yogyakarta:Tiara wacana.

Baron, A Robbert \& Donn Byrne, Psikologi social jilid 1. Jakarta: Erlangga 2005 
Calhoum Caplin. 1995. Psikologi Tentang Penyesuain dan hubungan Kemanusian Semarang: IKIP Press.

Crow Alice \& Lester D. Crow. 1990. Psikologi Pendidikan, Surabaya : PT. Bina Ilmu.

Dewa Ketut Sukardi. 2008. Proses Bimbingan Dan Konseling Di Sekolah. Jakarta: Rineka Cipta

Elizabeth E Hurlock. 2007. Perkembangan Anak. Jakarta: erlangga.

Fenigstein, A., Scheier, M. F., \& Buss, A. H. Public And Private Self-Consciousness: Assessment And Theory. Journal of Consulting and Clinical Psychology, 4 (4)3, 1975

Goleman, Daniel, Working With Emotional Intelligence, Kecerdasan Emosi Untuk Mencapai Puncak Prestasi, Terjemah Alex Tri Kantjono Widodo, Jakarta: PT Garamesia Pustaka Utama 1996

Ghozali, Imam. 2005. Aplikasi Analisis Multivariate dengan Program SPSS. Semarang: Universitas Diponegoro.

Hallen. A. 2005. Bimbingan dan Konseling. Jakarta: Ciputan Press.

Husain Usman. 1985. Metode Penelitian. Jakarta: Graha Indonesia.

Jane Elisabeth Allen. 2002. Disiplin Positif (Menciptakan Dunia Penitipan Anak yang Edukatif Bagi Anak Pra-Sekolah). Jakarta: Anak Prestasi Pustaka.

J.P. Chaplin. 2011. Kamus Lengkap Psikologi. Jakarta: Rajawali Pers. Kartono, Kartini. 2008. Patologi Sosial 2 Kenakalan Remaja. Jakarta: PT. Raja Grafindo Persada

Kartadinata, Sunaryo. 1997. Landasan Pendidikan Sekolah Dasar. Jakarta: Depdikbud.

Ketut Sukardi, Dewa. 2008. Pengantar Pelaksanaan Program Bimbingan dan Konseling di Sekolah. Jakarta : Rineka Cipta.

Koeswara. 1987. Psikologi Eksistensial Suatu Pengantar. Bandung: PT Eresco.

Malikah. 2013. Kesadaran Diri Proses Pembentukan Karakter Islam. Jurnal Al-Ulum Vol 13 (1).

Nawawi, Hadari. 1986. Metodelogi Penelitian Bidang Social. Yogyakarta: Gajah Mada University Press.

Nurul Zuriah. 2011. Pendidikan moral dan Budi pekerti. Jakarta: Bumi Akasara.

Patton, Patricia. 1998. Emosional Intelligence In The Workplace, Kecerdasan Emosional Di Tempat Kerja, Terjemah Zaenah Dahlan, Jakarta: Pustaka Delapratasa.

Prayitno, Erman Amti. 2004. Dasar-Dasar Bimbingan dan Konseling. Jakarta: Rineka Cipta 
